Board of Governors of the Federal Reserve System

International Finance Discussion Papers

Number 687

November 2000

\title{
OUTPUT AND INFLATION IN THE LONG RUN
}

Neil R. Ericsson, John S. Irons, and Ralph W. Tryon

NOTE: International Finance Discussion Papers are preliminary materials circulated to stimulate discussion and critical comment. References to International Finance Discussion Papers (other than an acknowledgment that the writer has had access to unpublished material) should be cleared with the author or authors. Recent IFDPs are available at www.federalreserve.gov/pubs/ifdp/ on the Web. 


\title{
OUTPUT AND INFLATION IN THE LONG RUN
}

\author{
Neil R. Ericsson, John S. Irons, and Ralph W. Tryon*
}

Abstract: Cross-country regressions explaining output growth often obtain a negative effect from inflation. However, that result is not robust, due to the selection of countries in sample, temporal aggregation, and omission of consequential variables in levels. This paper demonstrates some implications of these mis-specifications, both analytically and empirically. In particular, for most G-7 countries, annual time series of inflation and the log-level of output are cointegrated, thus rejecting the existence of a long-run relation between output growth and inflation. Typically, output and inflation are positively related in these cointegrating relationships: a price markup model helps interpret this surprising feature.

Keywords: cointegration, cross-country regression, economic growth, inflation, long run, output.

JEL classifications: F43, E3.

*The first and third authors are respectively a staff economist and an assistant director in the Division of International Finance, Board of Governors of the Federal Reserve System, Washington, D.C. 20551 U.S.A., and the second author is a professor in the Department of Economics, Amherst College, Amherst, Massachusetts 01002 U.S.A. The authors may be reached on the Internet at ericsson@frb.gov, jsirons@amherst.edu, and tryonr@frb.gov respectively. The views in this paper are solely the responsibility of the authors and should not be interpreted as reflecting the views of the Board of Governors of the Federal Reserve System or of any other person associated with the Federal Reserve System. We are grateful to Julia Campos, Jurgen Doornik, John Fernald, Stan Fischer, Joe Gagnon, Clive Granger, David Gruen, Dale Henderson, David Hendry, Matthew Higgins, David Howard, Ross Levine, Jaime Marquez, Grayham Mizon, Adrian Pagan, Hashem Pesaran, Sergio Rebelo, Hayden Smith, Ted Truman, Robert Wright, and three anonymous referees for helpful comments; to Ross Levine for providing us with the data from Levine and Renelt (1992); and to Jurgen Doornik and David Hendry for providing us with a beta-test version of GiveWin Version 2.0. All numerical results were obtained using PcGive Professional Version 9.2: see Doornik and Hendry (1996). Data and output listings for this paper's empirical results are available from the first author and at www.federalreserve.gov/pubs/ifdp/2000/687/default.htm on the WorldWide Web. 


\section{Introduction}

Many papers have investigated the empirical determinants of economic growth in a cross-country framework. This literature has two major strands. One uses crosscountry regressions to test alternative theories of economic growth. Romer (1986) inter alia sought to demonstrate that the stylized facts are consistent with endogenous growth models, while other authors have looked for evidence to support the neoclassical growth model; cf. Barro (1991) and Mankiw, Romer, and Weil (1992). A key empirical test in this debate is whether income (or output) growth rates are negatively correlated with the initial level of real income in a country. A negative correlation is interpreted to indicate that per capita real incomes in different countries tend to converge (as implied by the neoclassical model), whereas a zero correlation implies that income differentials persist indefinitely (as in endogenous growth models).

The second, older strand is primarily associated with development economics. It seeks to identify factors that are correlated with economic growth, with the aim of guiding policy to promote economic development. For example, many papers in this genre have looked at the correlation between output growth and exports, with the more-or-less explicit goal of demonstrating that free-trade policies promote exports and lead to more rapid economic development. Recent papers have broadened this approach to include variables such as the fiscal deficit, the inflation rate, and measures of financial structure and central bank independence; and they have begun examining the implications for policy in industrial as well as in developing countries; see Kormendi and Meguire (1985), Fischer (1991), Sala-i-Martin (1997), and Levine (1998).

The current paper investigates whether or not typical estimates of the relationship between output growth and inflation from cross-country regressions are relevant to the major industrial countries and, in particular, to the United States. Specifically, does a negative coefficient on inflation in such a cross-country growth regression imply that reducing U.S. inflation will lead to faster long-run output growth in the United States? The answer is "no" — that is, the implication does not follow. In standard regressions, the choice of countries in sample renders such inferences doubtful at best. Two additional complications - estimator bias due to invalid aggregation over time, and ignored cointegration due to omitted levels of variables - make existing inferences about long-run causality from inflation to output growth untenable. While the focus is on policy implications about inflation, the tripartite critique applies to the interpretation of cross-country growth regressions generally.

Alternatives to cross-country growth regressions exist, and they can yield novel results, as this paper shows. One natural approach is to analyze the data, country by country, with annual observations (rather than with the long time-averages typical of the literature), and to include the level of output. This approach entails a cointegration analysis of output and inflation, which also permits reinterpreting the 
existing cross-country results and the empirical presence of Granger causality between inflation and output growth. For most G-7 countries, output and inflation are cointegrated, thus rejecting the existence of a long-run relation between output growth and inflation. Surprisingly, output and inflation are positively related in nearly all of these cointegrating relationships. Models of wages and prices in Sargan (1964, 1980a, 1980b) provide a basis for interpreting this feature in the context of a price markup model.

This paper is organized as follows. Section 2 reviews typical empirical results on the relation between output growth and inflation as obtained from cross-country regression. Section 3 raises and empirically documents three problems with these studies: selection of countries, aggregation over time, and the use of only the growth rate of output rather than output's level as well. This section also tests for and interprets cointegration between output and inflation. Section 4 concludes.

\section{A Synopsis of Existing Cross-country Results}

This section summarizes existing cross-country regressions for output growth, first sketching their theoretical basis, and then examining a typical regression.

The theoretical framework for cross-country growth regressions is largely intuitive. The typical economic relation to be estimated is of the form:

$$
\Delta y=a_{0}+a_{1} y_{0}+a_{2} s_{k}+a_{3} s_{h}+a_{4} g+a_{5} \Delta p
$$

where $y$ is the log of real per capita income, $\Delta$ is the normalized difference operator over the whole time period (e.g., $\Delta y=\left(y_{1989}-y_{1960}\right) / 29$ in (2) below), $y_{0}$ is the initial level of real per capita income (possibly in levels, not logs), $s_{k}$ and $s_{h}$ are the savings rates for physical capital and human capital respectively, $g$ is the growth rate of the population, $\Delta p$ is inflation, and the $a_{i}$ 's are coefficients. This specification can be derived from the neoclassical growth model augmented to include the accumulation of human capital, as shown in Mankiw, Romer, and Weil (1992), Knight, Loayza, and Villanueva (1993), and Clark (1997). While inclusion of the inflation rate is essentially ad hoc, inflation can be viewed as influencing labor productivity in the Solow-Swan production function. The economic models behind (1) usually imply that $a_{2}$ and $a_{3}$ are positive, while $a_{1}, a_{4}$, and (presumably) $a_{5}$ are negative or at least non-positive. A negative coefficient on $y_{0}$ entails that income tends toward a steady-state level, conditional on the values of the other variables. This conditional convergence distinguishes the neoclassical growth model from the newer endogenous growth models.

A large and growing number of papers report variants on the basic cross-country growth regression (1). While country coverage, length of the sample, choice of righthand side variables, sources of data, and definitions of variables may differ across 
studies, the basic results are similar. Levine and Renelt (1991, 1992) summarize and replicate many of the key findings. Equation (2) replicates one such equation from Levine and Renelt (1992, Table 10) to illustrate.

$$
\begin{aligned}
& \widehat{\Delta y_{j}}=-\underset{(0.84)}{0.76}-\underset{(0.14)}{0.34} y_{0, j}+\underset{(2.7)}{17.3 I_{j}}+\underset{(1.3)}{3.2 H_{j}}-\underset{(0.22)}{0.37} g_{j}-\underset{(0.0023)}{0.0039 \Delta p_{j}} \\
& J=102 \quad \hat{\sigma}=1.374 \% .
\end{aligned}
$$

The subscript $j$ is the country index, $J$ is the number of countries in the sample, values in parentheses are estimated standard errors, and $\hat{\sigma}$ is the standard error of the equation. The regression variables are the average growth rate of real per capita GDP $(\Delta y)$, real per capita GDP in the initial period $1960\left(y_{0}\right)$, the average ratio of investment to GDP $(I)$, a measure of human capital $(H$, the rate of secondary school enrollment in the initial period), the average population growth rate $(g)$, and the average inflation rate based on the GDP deflator $(\Delta p)$, with the growth rates and inflation measured in percent per year. The underlying data are annual over 19601989 for 102 countries, with averages taken over 1960-1989; see Levine and Renelt (1992, Appendix) and Appendix A for details.

All estimated coefficients have the expected sign and are significant at (at least) the $10 \%$ level for a one-sided test. Human capital, as measured here, strongly affects output growth; and the negative coefficient on the initial level of income implies that per capita incomes in different countries tend to converge over time, conditional on the values of the other variables. The magnitude of the estimated inflation coefficient implies that a 10 percentage point increase in the steady-state annual inflation rate would reduce the annual growth rate of real output by only one twenty-fifth of a percentage point. Grier and Tullock (1989), Fischer (1991), Cozier and Selody (1992), Englander and Gurney (1994), Barro (1997), and Sala-i-Martin (1997) inter alia report the effect of inflation in cross-country growth regressions. Of these studies, all but the first and last find a statistically significant negative coefficient on inflation. Levine and Renelt (1992) show that the estimated inflation coefficient in (2) is fragile in Leamer's (1985) sense, although that sense of fragility could characterize estimated coefficients in a well-specified model. While the debate over growth regressions continues, these estimates are representative of the work to date.

\section{Problems with the Cross-country Analyses}

Numerous authors have raised methodological problems with estimating cross-country growth equations, including estimator bias, parameter heterogeneity, model fragility, measurement errors, and error autocorrelation; see the reviews by Levine and Renelt (1991) and Temple (1999), and the critique in Clark (1997). The current section focuses on three generic problems: selection of countries (Section 3.1), aggregation over 

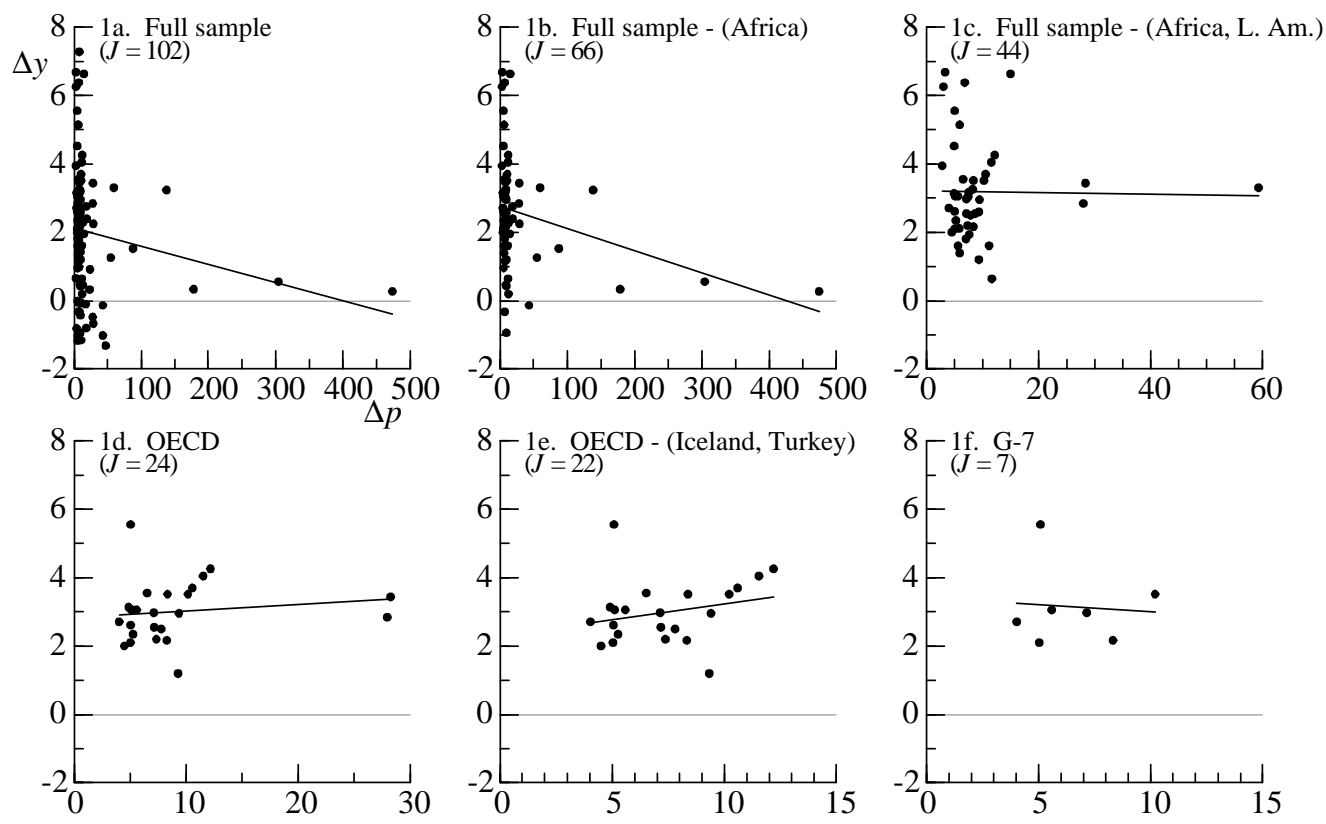

Figure 1: Cross-plots of average annual output growth $(\Delta y)$ against average annual inflation $(\Delta p)$ for the full sample of countries and for five country subsamples.

time (Section 3.2), and the use of differences in variables, to the exclusion of their levels (Section 3.3). These three issues are well-known in the economics literature as a whole. However, in the cross-country growth literature, the first two issues generally are acknowledged and then are swept under the rug, despite being empirically important (as shown below). The third issue has gone unnoticed, even while implying a substantive reinterpretation of the standard regressions through the empirical presence of cointegration between output and inflation. Section 3.4 further elucidates the empirical cointegration results in a yet more general cointegrating framework.

\subsection{Selection Of Countries}

Many researchers have questioned the appropriateness of running cross-country regressions on a sample that includes a substantial fraction of all countries in the world. Even if the countries chosen use a single production technology, institutions and policies differ dramatically across countries, so the effects of inflation on production in Switzerland (say) might differ from its effects in Chile or Lesotho.

The statistical and economic significance of inflation in (2) is in fact sensitive to country coverage, as both graphs and additional regressions highlight. Figure 1 plots average annual output growth (vertical axis) against average annual inflation (horizontal axis) for six different country groupings: all 102 countries in the sample, 
all countries except for those in Africa, all countries except for those in Africa and Latin America, the OECD countries, the OECD countries except for Iceland and Turkey, and the G-7 countries. The data are averages over 1960-1989, in percent, as taken from Levine and Renelt (1992). Each panel in Figure 1 also includes the least squares line corresponding to the bivariate regression of output growth on inflation. In each sample or subsample, the regression results are dominated by a few highinflation countries, with those countries' inflation rates being far larger than those for the rest of the (sub)sample. Countries with the highest inflation rates are chiefly in Latin America: excluding Africa from the sample does not change the picture significantly, whereas the effect of excluding Latin America is very much evident.

The heterogeneity within the full sample can be shown more formally by regression. If dummy variables for all of the Latin American and African countries are added to (2), the $F$-statistic for the significance of those dummies is $F(58,38)=2.51$ with a $p$-value of $0.16 \%$. Thus, the selection of countries implicit in (2) is rejected.

One response is to exclude Latin America and Africa from the sample, as in (3).

$$
\begin{aligned}
& \widehat{\Delta y_{j}}=\underset{(1.06)}{0.38}-\underset{(0.12)}{0.38} y_{0, j}+\underset{(3.4)}{18.4 I_{j}}+\underset{(1.1)}{1.1 H_{j}}-\underset{(0.22)}{0.48} g_{j}+\underset{(0.0174)}{0.0024 \Delta p_{j}} \\
& J=44 \hat{\sigma}=0.9926 \%
\end{aligned}
$$

The sign of the regression coefficient on inflation switches, although it is now both statistically insignificant and numerically close to zero. However, selection of even these 44 countries or subsets of them may be problematic. From Figure 1c, one country has a much higher inflation rate than the rest (Israel, at 59\%). Figures 1d-1f provide additional graphical detail for the (then) 24 OECD countries. Two outliers - Turkey and Iceland - have an obvious effect on the simple correlation of inflation and output growth. Apart from Turkey and Iceland, four other OECD countries Portugal, Greece, Spain, and Italy - average over 10 percent inflation and 3.5 percent real per capita output growth annually. For comparison, the United States and Japan have average inflation rates of 5.0 and 5.1 percent and average real per capita output growth rates of 2.1 and 5.6 percent. While additional factors may determine output growth in the industrial countries, little, if any, relationship is apparent between their growth and inflation, at least when averaged over such a long period.

\subsection{Aggregation Over Time}

Inflation and real output growth may be jointly determined, introducing the usual

problems of simultaneity in estimation. Even if inflation and real output growth are contemporaneously uncorrelated at the original observation frequency, aggregation of the data over time typically induces simultaneity if either inflation or output growth causes the other in the sense of Granger (1969). For cross-country regressions, where the data are averaged over decades, such induced simultaneity seems particularly 
likely. Because of that averaging, the estimated coefficient can easily differ in sign and magnitude from the underlying parameter, even asymptotically. Specifically, temporal aggregation could induce an apparent relationship even if no relationship is present; and it could induce an apparent lack of relationship even if one is present. To clarify the importance of temporal aggregation for cross-country regressions, this subsection presents analytical results for a first-order vector autoregression (VAR) and then documents the empirical prevalence of Granger causality between annual inflation and output growth for the $\mathrm{G}-7$ countries.

Consider a bivariate system for output growth and inflation, with each variable depending on only the other variable's lag and an independent random error:

$$
\left[\begin{array}{c}
\Delta y \\
\Delta p
\end{array}\right]_{t}=\left[\begin{array}{ll}
0 & a \\
b & 0
\end{array}\right]\left[\begin{array}{l}
\Delta y \\
\Delta p
\end{array}\right]_{t-1}+\left[\begin{array}{l}
e \\
u
\end{array}\right]_{t} \quad\left[\begin{array}{l}
e \\
u
\end{array}\right]_{t} \sim N I\left(\left[\begin{array}{l}
0 \\
0
\end{array}\right],\left[\begin{array}{ll}
\sigma_{e}^{2} & 0 \\
0 & \sigma_{u}^{2}
\end{array}\right]\right) .
$$

The subscript $t$ is the time index, with its frequency corresponding to the natural timing of the relationships between $\Delta y_{t}$ and $\Delta p_{t}$; and $\Delta y_{t}=y_{t}-y_{t-1}$ and $\Delta p_{t}=$ $p_{t}-p_{t-1}$. The coefficients $a$ and $b$ measure the feedback between $\Delta y$ and $\Delta p$, with $a \neq 0$ implying Granger causality from $\Delta p$ to $\Delta y$, and $b \neq 0$ implying Granger causality from $\Delta y$ to $\Delta p$. The independent random errors $e_{t}$ and $u_{t}$ have zero means and variances $\sigma_{e}^{2}$ and $\sigma_{u}^{2}$. Normality of $\left(e_{t}: u_{t}\right)^{\prime}$ and stationarity of $\left(\Delta y_{t}: \Delta p_{t}\right)^{\prime}$ are assumed for convenience. Because $\operatorname{corr}\left(e_{t}, u_{t}\right)=0$, then $\mathcal{E}\left(\Delta y_{t} \Delta p_{t}\right)=0$ by repeated substitution, and hence the probability limit (plim, for $J \rightarrow \infty$, with the time series sample size $T$ fixed) of the estimator from regressing $\Delta y_{t}$ on $\Delta p_{t}$ is also zero.

Now turn to regression with two-period averages of $\Delta y_{t}$ and $\Delta p_{t}$, denoted $\Delta y_{t}^{*}$ and $\Delta p_{t}^{*}$ and defined as $\Delta y_{t}^{*}=\left(\Delta y_{t}+\Delta y_{t-1}\right) / 2$ and $\Delta p_{t}^{*}=\left(\Delta p_{t}+\Delta p_{t-1}\right) / 2$. Using (4), it can be shown that the plim of the estimator from regressing $\Delta y_{t}^{*}$ on $\Delta p_{t}^{*}$ is:

$$
\operatorname{plim} \hat{c}=\left(a+b s^{2}\right) / 2,
$$

where $\hat{c}$ is the estimated coefficient, $s^{2} \equiv \operatorname{var}\left(\Delta y_{t}\right) / \operatorname{var}\left(\Delta p_{t}\right)=\left(a^{2}+r^{2}\right) /\left(1+b^{2} r^{2}\right)$, and $r^{2} \equiv \sigma_{e}^{2} / \sigma_{u}^{2}$; see Appendix B. Notably, the plim in (5) need not be zero (where zero is the value of the plim with unaveraged data); nor need the plim in (5) have the same sign or magnitude as $a$, or as $b$. Figure 2 displays this lack of simple correspondence, plotting plim $\hat{c}$ (vertical axis) as a function of the feedback parameters $a$ and $b$ (horizontal axes) for $r^{2}=1 .^{1}$

Depending upon the feedback coefficients $a$ and $b$, the coefficient from regressing averaged output growth on averaged inflation could be positive, negative, or zero, even if the original unaveraged variables are contemporaneously uncorrelated, and even in large samples. Furthermore, plim $\hat{c}$ could be zero for nonzero $a$ and $b$; and

\footnotetext{
${ }^{1}$ For comparison, $\operatorname{corr}\left(\Delta y_{t}^{*}, \Delta p_{t}^{*}\right)=\left(a s^{-1}+b s\right) / 2$ for two-period averages. Similar results hold for general $m$-period averages, but the formulae are more complicated and provide little additional insight for the problem at hand.
} 




Figure 2: The asymptotic regression coefficient plim $\hat{c}$ for two-period averaging, as a function of the parameters $a$ and $b$.

the economically small and (for (3)) statistically insignificant coefficients on inflation in (2) and (3) are consistent with large nonzero feedbacks from inflation onto output growth and from output growth onto inflation.

While the formula in (5) is specific to the simple VAR in (4), the lack of correspondence between $\operatorname{corr}\left(\Delta y_{t}, \Delta p_{t}\right.$ ) (or either $a$ or $b$ ) alone and plim $\hat{c}$ carries over to generic, multiple lag, multivariate VARs, with the algebra being closely related to that of NBER phase averaging; see Campos, Ericsson, and Hendry (1990). Instrumental variable estimation (including GMM) typically does not solve this problem: instruments at time $t$ are likely to depend upon lagged output growth and/or lagged inflation, thus inducing spurious contemporaneous correlation between the time-averaged instruments and time-averaged output growth. Hence, under the weak assumption that some process links inflation and output growth at a frequency of less than three decades, standard time-averaged cross-country regressions of output growth on inflation are unlikely to provide economically meaningful estimates of their underlying relationship, regardless of whether the resulting estimates are statistically significant or not, and regardless of whether the resulting estimates are economically "sensible" or not.

To demonstrate the empirical relevance of the analytical example above, the remainder of this subsection tests for Granger non-causality between inflation and out- 
Table 1. Statistics for Testing Granger Non-causality.

\begin{tabular}{|c|c|c|c|c|c|c|}
\hline \multirow{3}{*}{ Country } & \multicolumn{6}{|c|}{ Null hypothesis } \\
\hline & \multicolumn{2}{|c|}{$\Delta p \nrightarrow \Delta y$} & \multicolumn{2}{|c|}{$\Delta y \nrightarrow \Delta p$} & \multicolumn{2}{|c|}{$\Delta y \leftrightarrow \Delta p$} \\
\hline & $t$-ratio & $p$-value & $t$-ratio & $p$-value & $\chi^{2}(2)$ & $p$-value \\
\hline Canada & -0.62 & 0.538 & $4.04^{* *}$ & 0.000 & $16.7^{* *}$ & 0.000 \\
\hline France & $-2.09^{*}$ & 0.044 & -0.06 & 0.948 & 4.4 & 0.110 \\
\hline Germany & $-2.89^{* *}$ & 0.006 & 0.45 & 0.655 & $8.4^{*}$ & 0.015 \\
\hline Italy & $-3.82^{* *}$ & 0.000 & 2.01 & 0.051 & $21.3^{* *}$ & 0.000 \\
\hline Japan & -0.86 & 0.395 & $2.38^{*}$ & 0.022 & $6.1^{*}$ & 0.048 \\
\hline United Kingdom & -1.39 & 0.172 & $3.03^{* *}$ & 0.004 & $9.9^{* *}$ & 0.007 \\
\hline United States & $-2.44^{*}$ & 0.020 & $4.48^{* *}$ & 0.000 & $25.9^{* *}$ & 0.000 \\
\hline
\end{tabular}

Notes: The sample period is 1953-1992 $(T=40)$. All models estimated are first-order VARs, which, based on the Schwarz criterion, are statistically adequate simplifications of second-order VARs. Asterisks ${ }^{*}$ and ${ }^{* *}$ denote significance at the $5 \%$ and $1 \%$ levels, i.e., Granger non-causality " $\nrightarrow$ " is rejected.

put growth in the G-7 countries: Canada, France, Germany, Italy, Japan, the United Kingdom, and the United States. The data are annual from 1953 through 1992. To maintain comparability with cross-section regression results, chain-weighted real per capita output is taken from Summers and Heston's (1991) Mark 5.6 database (variable RGDPCH). Inflation is constructed from the consumer price index in the International Monetary Fund's International Financial Statistics (line 64). See Appendix A for details.

Table 1 lists the results for testing Granger non-causality in bivariate VARs of $\Delta y_{t}$ and $\Delta p_{t}$, with test rejection implying Granger causality. Inflation Granger-causes output growth in Germany and Italy at the $99 \%$ level, and in France and the United States at the $95 \%$ level. In Canada, Japan, and the United Kingdom, there is no evidence of Granger causality from inflation to output growth. Granger causality in the other direction is more prevalent: output growth Granger-causes inflation in Canada, the United Kingdom, and the United States at the 99\% level, in Japan at the $95 \%$ level, and in Italy at the $90 \%$ level. Granger causality in at least one direction is statistically significant at the $95 \%$ level in all but one country (France).

This prevalence of Granger causality implies that estimator bias from induced simultaneity is an empirical problem for cross-country regressions using temporal aggregates of such data. Because inflation is often not strictly exogenous empirically, the proposed bias correction in Evans (1997) for cross-country regressions is inapplicable. Furthermore, a likelihood ratio test strongly rejects equality across countries of the lag coefficients in Table 1's models: $\chi^{2}(24)=55.9$ with a $p$-value of $0.02 \%$. The lag structure for inflation and output differs across countries, countering again the hypothesis of an output-inflation relationship that is constant across countries. 
Hendry and Mizon (1999) discuss additional implications of such pervasive Granger causality.

\subsection{Differences versus Levels of Output}

The standard cross-country growth regression and the VAR for the Granger-causality tests above both assume a relationship between inflation and the growth rate of real output. A more general specification would allow for a relationship between inflation, the (log-) level of output, and their lags, with a relationship involving the growth rate of real output being a restriction on the dynamics of the relationship in levels; see Hendry, Pagan, and Sargan (1984).

This subsection thus tests for cointegration between inflation and output, country by country for the $\mathrm{G}-7$, and interprets the results in an error correction framework. The data are the same as for the Granger-causality tests. For France, Japan, the United Kingdom, the United States, and possibly Italy, cointegration exists between the log-level of output, inflation, and a linear trend, with a positive relation between output and inflation. This finding precludes a long-run relationship between output growth and inflation. That is, if output and inflation are cointegrated, then the growth rate of output is unrelated to the inflation rate in the long run. The combined results on Granger causality and cointegration imply that the cross-country regressions in decades-long averages are interpretable as dynamically confounded short-run relationships.

To test for cointegration, a bivariate VAR in $\left(y_{t}: \Delta p_{t}\right)^{\prime}$ is estimated for each country on the annual data from Section 3.2. ${ }^{2}$ An intercept and a linear trend $t$ are included; and the linear trend is restricted to enter the cointegrating vector, as it seems unlikely that either output or inflation would have a quadratic deterministic trend. Based on the Schwarz criterion, all models estimated are first-order VARs, except for Canada, which is a second-order VAR.

Table 2 presents the eigenvalues and related likelihood-ratio statistics from Johansen's (1991) procedure for testing for cointegration. There is clear evidence of a single cointegrating relationship for France, Japan, the United Kingdom, and the United States. For Italy, the evidence is borderline, with cointegration detectable at the $10 \%$ level; and Germany appears to have two cointegrating vectors, implying that both output and inflation are trend-stationary. Canada is the only country in the G-7 for which cointegration is not apparent.

\footnotetext{
${ }^{2}$ Evidence from augmented Dickey-Fuller tests and Johansen's system-based unit root test for each G-7 country is generally consistent with output and inflation both having a unit root. That result implies a balance problem in cross-country growth regressions, in that output growth is $\mathrm{I}(0)$ whereas inflation is $\mathrm{I}(1)$. Balance in such a situation requires the presence of an additional I(1) regressor or regressors, and furthermore it requires that those I(1) regressors (including inflation) cointegrate among themselves. Even with such balance, some inferences would be non-standard.
} 
Table 2. Cointegration Results: Eigenvalues, Cointegration Test Statistics, and Estimates of the Cointegrating Vector $\beta$ and Weighting Matrix $\alpha$.

\begin{tabular}{|c|c|c|c|c|c|c|c|c|}
\hline \multirow[t]{2}{*}{ Country } & \multirow{2}{*}{$\begin{array}{l}\text { Eigen- } \\
\text { values }\end{array}$} & \multicolumn{2}{|c|}{ Statistic } & \multicolumn{3}{|c|}{ Estimate of $\beta^{\prime}$} & \multicolumn{2}{|c|}{ Estimate of $\alpha^{\prime}$} \\
\hline & & $\max$ & trace & $y$ & $\Delta p$ & trend & $\Delta y$ & $\Delta^{2} p$ \\
\hline Canada & $\begin{array}{l}0.304 \\
0.081\end{array}$ & $\begin{array}{r}13.0 \\
3.0\end{array}$ & $\begin{array}{r}16.1 \\
3.0\end{array}$ & $1^{* *}$ & $\begin{array}{l}-2.03^{* *} \\
(0.47)\end{array}$ & $\begin{array}{c}-0.025^{* *} \\
(0.001)\end{array}$ & $\begin{array}{c}-0.145 \\
(0.108)\end{array}$ & $\begin{array}{c}0.136^{* *} \\
(0.039)\end{array}$ \\
\hline France & $\begin{array}{l}0.647 \\
0.224\end{array}$ & $\begin{array}{l}39.5^{* *} \\
9.6\end{array}$ & $\begin{array}{c}49.2^{\text {** }} \\
9.6\end{array}$ & $1^{* *}$ & $\begin{array}{c}-3.30^{* *} \\
(0.41)\end{array}$ & $\begin{array}{c}-0.033^{* *} \\
(0.001)\end{array}$ & $\begin{array}{c}0.083^{* *} \\
(0.020)\end{array}$ & $\begin{array}{c}0.189^{* *} \\
(0.039)\end{array}$ \\
\hline Germany & $\begin{array}{l}0.476 \\
0.331\end{array}$ & $\begin{array}{l}24.6^{* *} \\
15.3^{*}\end{array}$ & $\begin{array}{l}39.9^{* *} \\
15.3^{*}\end{array}$ & 1 & $\begin{array}{l}261.96 \\
(62.51)\end{array}$ & $\begin{array}{c}0.251 \\
(0.101)\end{array}$ & $\begin{array}{c}-0.003^{* *} \\
(0.001)\end{array}$ & $\begin{array}{c}-0.0005 \\
(0.0003)\end{array}$ \\
\hline Italy & $\begin{array}{l}0.357 \\
0.153\end{array}$ & $\begin{array}{r}16.8 \\
6.3\end{array}$ & $\begin{array}{r}23.0 \\
6.3\end{array}$ & 1 & $\begin{array}{c}-9.91^{*} \\
(3.28)\end{array}$ & $\begin{array}{c}-0.056 \\
(0.015)\end{array}$ & $\begin{array}{c}0.023^{* *} \\
(0.005)\end{array}$ & $\begin{array}{c}0.010 \\
(0.006)\end{array}$ \\
\hline Japan & $\begin{array}{l}0.575 \\
0.156\end{array}$ & $\begin{array}{c}32.5^{\text {** }} \\
6.4\end{array}$ & $\begin{array}{c}38.9^{* *} \\
6.4\end{array}$ & $1^{* *}$ & $\begin{array}{c}-5.70^{* *} \\
(0.76)\end{array}$ & $\begin{array}{c}-0.066^{* *} \\
(0.003)\end{array}$ & $\begin{array}{c}0.088^{* *} \\
(0.022)\end{array}$ & $\begin{array}{l}0.082^{* *} \\
(0.022)\end{array}$ \\
\hline $\begin{array}{l}\text { United } \\
\text { Kingdom }\end{array}$ & $\begin{array}{l}0.450 \\
0.199\end{array}$ & $\begin{array}{c}22.7^{*} \\
8.4\end{array}$ & $\begin{array}{l}31.1^{* *} \\
8.4\end{array}$ & $1^{* *}$ & $\begin{array}{c}-0.29 \\
(0.13)\end{array}$ & $\begin{array}{c}-0.021^{* *} \\
(0.001)\end{array}$ & $\begin{array}{c}-0.166 \\
(0.118)\end{array}$ & $\begin{array}{c}0.662^{* *} \\
(0.123)\end{array}$ \\
\hline $\begin{array}{l}\text { United } \\
\text { States }\end{array}$ & $\begin{array}{l}0.489 \\
0.175\end{array}$ & $\begin{array}{c}25.5^{* *} \\
7.3\end{array}$ & $\begin{array}{c}32.8^{\text {** }} \\
7.3\end{array}$ & $1^{* *}$ & $\begin{array}{c}-1.19^{* *} \\
(0.25)\end{array}$ & $\begin{array}{c}-0.018^{* *} \\
(0.001)\end{array}$ & $\begin{array}{c}0.003 \\
(0.115)\end{array}$ & $\begin{array}{c}0.323^{* *} \\
(0.054)\end{array}$ \\
\hline
\end{tabular}

Notes: The sample period is $1953-1992(T=40)$. For a given country and type of cointegration test statistic (max or trace), two values are reported, the first corresponding to a null hypothesis of no cointegrating vectors, and the second to a null hypothesis of no more than one cointegrating vector. Both statistics are adjusted for degrees of freedom used in estimation. The $95 \%$ critical values are 19.0 and 12.3 for the max statistic and 25.3 and 12.3 for the trace statistic; see Osterwald-Lenum (1992). For the estimates of $\beta$ and $\alpha$, one cointegrating vector is assumed, values in parentheses are estimated standard errors, estimates of $\alpha$ are reported by equation, and indicators of significance are based on the likelihood ratio statistic.

Table 2 also reports the estimated parameters of the cointegrating vector $\beta$ and of the weighting (or feedback) coefficient vector $\alpha$, assuming a single cointegrating vector. The cointegrating coefficients on inflation and the linear trend are all negative except for Germany's; and the cointegrating coefficients on output, inflation, and the linear trend generally are statistically significant. For example, the cointegrating combination for the United States implies the following long-run relationship:

$$
y_{t}=\underset{(0.25)}{1.19} \Delta p_{t}+\underset{(0.001)}{0.018 t}+\mathrm{I}(0) .
$$

In equilibrium, output grows at 1.8 percent per annum, with output relative to its trend related positively to the level of inflation. From Table 2, output is statistically significant in the cointegrating relationship, implying that inflation is $\mathrm{I}(1)$, not $\mathrm{I}(0)$. The cointegrating relationships for France, Italy, Japan, and the United Kingdom have similar interpretations. Thus, for the five G-7 countries with single cointegrating relationships, output growth and inflation are not related in the long run, contrary to the assumed structure in cross-country growth regressions such as (2). 
Such cointegration relationships are consistent with a long-run non-vertical Phillips curve or (e.g.) a Walrasian demand system with underlying technological growth in which excess demand fuels inflation. See also Ahmed and Rogers (2000), who find a positive long-run relationship between output and inflation on a century of annual U.S. data.

Feedback from disequilibria occurs in either or both equations, depending upon the country. For the United States, feedback onto output is numerically small and statistically insignificant, whereas feedback onto inflation is a highly significant $+32 \%$ per annum. That is, inflation — not output — adjusts to disequilibria between inflation and output. The United Kingdom behaves similarly, whereas output alone appears responsible for adjusting to disequilibrium in Italy; and both output and inflation adjust in France and Japan. Marked differences in cointegrating coefficients and feedback coefficients for even these $\mathrm{G}-7$ countries point to a fundamental heterogeneity present in the data.

The empirical nonstationarity of inflation may be perplexing economically. One potential explanation is that inflation is actually stationary, but appears nonstationary due to structural breaks. From that perspective, Table 2 implies that inflation and output co-break for several of the $\mathrm{G}-7$ countries, noting that tests of cointegration may also detect co-breaking; see Campos, Ericsson, and Hendry (1996) and Hendry and Mizon (1998).

While the interpretation of the cointegrating vectors in Table 2 is open to discussion, their empirical presence has direct implications for the modeling of output and inflation. First, typical cross-country analyses omit "levels" and so estimate short-run rather than long-run effects. Second, use of averaged data in cross-country studies confounds the short-run relationship between output and inflation, given the results on Granger causality.

Moreover, dynamic heterogeneous panel data models are not immediately promising, contrasting with the views in (e.g.) Temple (1999, Sections 4 and 5). Panel models of output alone, as in Lee, Pesaran, and Smith (1997), ignore the empirical cointegration of output with inflation for several countries, a property that heavily qualifies results from their univariate framework. Dynamic heterogeneous panel data models generalized to a multivariate basis also have difficulties. Assuming a single cointegrating vector for each bivariate country model in Table 2, a likelihood ratio test strongly rejects equality of those cointegrating vectors: $\chi^{2}(12)=80.0$ with a $p$-value of $0.00 \%$. Distributional properties for inference are yet to be derived for the empirically relevant situation in which the number of cointegrating vectors differs across countries. Short-run dynamics are also country-specific, noting that Canada requires two lags whereas the other countries need only one. 


\subsection{Reinterpretations and a Prospectus}

A long-run non-vertical Phillips curve such as (6) sits uncomfortably alongside standard economic theories of inflation and output, so two reinterpretations are given. First, a short-run trade-off between output and inflation may be prolonged and substantial; see Church, Mitchell, and Wallis (1998) and Hutchison and Walsh (1998). As such, that trade-off might appear to be long-run empirically, hence generating the cointegration results obtained.

Second, those cointegrating relationships may themselves be mis-specified, with a more fundamental reconciliation of theory and evidence foreshadowed by Sargan's empirical modeling of wages and prices: initially in Sargan (1964), and with further refinements in Sargan (1980a, 1980b). In particular, the cointegration analysis in Section 3.3 above omits the log-level of prices, which may cointegrate with other omitted variables such as wages (or unit labor costs) and import prices. If longrun price homogeneity is satisfied, the corresponding error correction term for those levels would imply a markup model for prices, with the markup depending upon the output gap as proxied by the detrended output from (6). In such markup models, the verticality of the Phillips curve is generally a system property rather than a singleequation property. The determinants (and especially the dynamics) of the equation for wages or unit labor costs bear directly on the long-run relation between inflation and some measure of slack. Markup models have been empirically successful for modeling prices of several OECD countries; see inter alia Franz and Gordon (1993) for Germany and the United States, Church, Mitchell, and Wallis (1998) for the United Kingdom, and de Brouwer and Ericsson (1998) for Australia. Investigation of such additional cointegration is thus highly promising and economically motivated, but would require an empirical analysis well beyond the scope of this paper.

\section{Conclusions}

The negative correlation between inflation and output growth obtained by crosscountry regression is not robust to changes in model specification. The selection of countries in the sample, the level of aggregation over time, and the choice of dynamic specification all affect the results obtained.

Empirically, the relationship between output and inflation for Africa and Latin America appears statistically different from the relationship between output and inflation for other countries. If Africa and Latin America are dropped from the sample, the coefficient on inflation in the growth regression becomes positive and statistically insignificant. For the OECD countries by themselves, no economically important, statistically detectable, long-run relation appears to exist between output growth and inflation.

Averaging data over time can introduce a contemporaneous correlation between 
time-averaged variables, even if the original series are not contemporaneously correlated. Both the sign and magnitude of the induced correlation can differ from those in the underlying data. Because output growth and inflation generally Grangercause each other in the $\mathrm{G}-7$ countries on annual data, cross-country regressions using decades-long averages confound the dynamics of the underlying process and are unlikely to yield economically meaningful results.

Cross-country regressions typically restrict the relationship between prices and output to be in growth rates, precluding the possibility of a relation between inflation and the level of output. Analysis of annual data detects cointegration between inflation and the level of output in all G-7 countries except Canada and Germany. Depending upon the country, adjustment to disequilibrium occurs in either the inflation equation, the output equation, or both. These empirical results suggest that no long-run relationship exists between output growth and inflation in these countries.

Standard cross-country growth regressions thus impose a single output-inflation relationship across countries with different actual relationships, confound dynamics from both inflation and output equations, and misconstrue short-run for long-run properties. These regressions are a doubtful and misleading basis for inferences about economic policy. While the empirical analysis herein is specific to output growth equations, the conceptual framework applies to time-aggregated cross-country regressions in general. Such regressions are still common in the literature, and the caveats noted above are typically disregarded, as in Sala-i-Martin (1997) and Levine and Zervos (1998).

In a more positive vein, modeling of the time series data on a country-by-country basis has already provided insights into long-run relationships between output and inflation and between prices and their determinants. Once an array of country-specific models is developed, their comparison across countries may shed further light on the economics and policy implications of these relationships. 


\section{Appendix A. Data}

This appendix describes the two datasets utilized in this paper: one for cross-country regressions (Section A.1) and the other for time series analysis (Section A.2). These datasets, the output for the results in this paper, and the corresponding PcGive batch files are available in electronic format from the first author and at:

www.federalreserve.gov/pubs/ifdp/2000/687/default.htm

on the WorldWide Web.

\section{A.1 Data for the Cross-country Regressions}

The empirical results in Section 2 and Section 3.1 use Levine and Renelt's (1992) dataset Dat6089.wk1, which was initially provided by Ross Levine and is now available at www.worldbank.org/research/growth/ddlevren.htm on the World Bank's website. This section briefly describes the data series used and the subsamples of countries considered.

Table A1 lists the variables in the current paper's cross-country regressions.

Table A1. Choice of Variables in the Cross-country Regressions.

\begin{tabular}{cccll}
\hline \hline & Notation & & & Description \\
$\begin{array}{c}\text { Levine and } \\
\text { Renelt } \\
(1992)\end{array}$ & Dat6089.wk1 & $\begin{array}{c}\text { the } \\
\text { current } \\
\text { paper }\end{array}$ & & $\begin{array}{c}\text { Original } \\
\text { Source }\end{array}$ \\
\hline GYP & GYP6089 & $\Delta y$ & Growth rate of real per capita GDP & WBNA \\
RGDP60 & RGDP60 & $y_{0}$ & Real GDP per capita in 1960 & SH \\
GPO & GPO6089 & $g$ & Growth rate of the population & WBSI \\
SEC & SEC & $H$ & Secondary school enrollment rate in 1960 & Barro (1991) \\
INV & INV6089 & $I$ & Investment share of GDP & WBNA \\
PI & PI6089 & $\Delta p$ & Average inflation of the GDP deflator & WBNA \\
& & & & \\
\hline
\end{tabular}

The original data sources are the World Bank National Accounts (WBNA), World Bank Social Indicators (WBSI), the Summers-Heston dataset (SH, see Section A.2 below), and Barro (1991). See Levine and Renelt (1992, Data Appendix) for additional details. Inflation, the growth rates $\Delta y$ and $g$, and the investment share are all annual averages over 1960-1989.

Sections 2 and 3.1 above analyze data for six choices of countries. Each sample of countries is denoted by the number of countries $J$ in the sample, and the samples are nested. Table A2 indicates which countries are in each of the six samples.

Levine and Renelt (1992) start with 119 countries total, and these are listed in Table A2, along with Levine and Renelt's country index. (Note that this index 
differs from those of Barro (1991) and Summers and Heston (1991).) The sample in equation (2) above is $J=102$, which, relative to the full sample of 119 countries, excludes 10 oil-producing countries and 7 countries with missing observations. The sample $J=66$ in addition excludes all 36 remaining sub-Saharan countries. The sample $J=44$ further excludes all 22 remaining Latin American countries. The sample $J=24$ contains all 24 countries that were members of the Organization for Economic Co-operation and Development (OECD) on December 1990. The sample $J=22$ contains all OECD countries except Iceland and Turkey. The sample $J=7$ contains the G-7 countries. The definitions of oil-producing, sub-Saharan, Latin American, and OECD countries correspond to the dummy variables OIL, AFRICA, LAAM, and OECD in Levine and Renelt's (1992) dataset Dat6089.wk1, noting the exclusions due to missing observations.

\section{A.2 Annual Time Series Data}

Sections 3.2 and 3.3 above use two annual data series for each of the G-7 countries (Canada, France, Germany, Italy, Japan, the United Kingdom, and the United States). The series are chain-weighted real GDP per capita in constant dollars (expressed in international prices, base 1985) and the consumer price index $(1995=100)$. The first is the series RGDPCH from Summers and Heston's Mark 5.6a Penn World Tables, available at www.pwt.econ.upenn.edu on the WorldWide Web. The second is the series on line 64 from the International Monetary Fund's International Financial

Statistics (various issues), as downloaded from the Federal Reserve Board's online version of that publication. 
Table A2. Choice of Countries for Various Samples.

\begin{tabular}{|c|c|c|c|c|c|c|c|}
\hline \multirow[t]{2}{*}{$\overline{\text { Index }}$} & \multirow[t]{2}{*}{ Country } & \multicolumn{6}{|c|}{ Number of Countries $J$ in Sample } \\
\hline & & $J=102$ & $J=66$ & $J=44$ & $J=24$ & $J=22$ & $J=7$ \\
\hline 1 & Afghanistan & & & & & & \\
\hline 2 & Algeria & & & & & & \\
\hline 3 & Angola & $\star$ & & & & & \\
\hline 4 & Argentina & $\star$ & $\star$ & & & & \\
\hline 5 & Australia & $\star$ & $\star$ & $\star$ & $\star$ & $\star$ & \\
\hline 6 & Austria & $\star$ & $\star$ & $\star$ & $\star$ & $\star$ & \\
\hline 7 & Bangladesh & $\star$ & $\star$ & $\star$ & & & \\
\hline 8 & Barbados & $\star$ & $\star$ & & & & \\
\hline 9 & Belgium & $\star$ & $\star$ & $\star$ & $\star$ & $\star$ & \\
\hline 10 & Bolivia & $\star$ & $\star$ & & & & \\
\hline 11 & Botswana & $\star$ & & & & & \\
\hline 12 & Brazil & $\star$ & $\star$ & & & & \\
\hline 13 & Burundi & $\star$ & & & & & \\
\hline 14 & Cameroon & $\star$ & & & & & \\
\hline 15 & Canada & $\star$ & $\star$ & $\star$ & $\star$ & $\star$ & $\star$ \\
\hline 16 & Central African Republic & $\star$ & & & & & \\
\hline 17 & Chad & $\star$ & & & & & \\
\hline 18 & Chile & $\star$ & $\star$ & & & & \\
\hline 19 & Colombia & $\star$ & $\star$ & & & & \\
\hline 20 & Congo & $\star$ & & & & & \\
\hline 21 & Costa Rica & $\star$ & $\star$ & & & & \\
\hline 22 & Cote D'Ivoire & $\star$ & & & & & \\
\hline 23 & Cyprus & $\star$ & $\star$ & $\star$ & & & \\
\hline 24 & Denmark & $\star$ & $\star$ & $\star$ & $\star$ & $\star$ & \\
\hline 25 & Dominican Republic & $\star$ & $\star$ & & & & \\
\hline 26 & Ecuador & $\star$ & $\star$ & & & & \\
\hline 27 & Egypt & $\star$ & $\star$ & $\star$ & & & \\
\hline 28 & El Salvador & $\star$ & $\star$ & & & & \\
\hline 29 & Ethiopia & $\star$ & & & & & \\
\hline 30 & Fiji & $\star$ & $\star$ & $\star$ & & & \\
\hline 31 & Finland & $\star$ & $\star$ & $\star$ & $\star$ & $\star$ & \\
\hline 32 & France & $\star$ & $\star$ & $\star$ & $\star$ & $\star$ & $\star$ \\
\hline 33 & Gabon & & & & & & \\
\hline 34 & Gambia & $\star$ & & & & & \\
\hline 35 & Germany & $\star$ & $\star$ & $\star$ & $\star$ & $\star$ & $\star$ \\
\hline 36 & Ghana & $\star$ & & & & & \\
\hline 37 & Greece & $\star$ & $\star$ & $\star$ & $\star$ & $\star$ & \\
\hline 38 & Guatemala & $\star$ & $\star$ & & & & \\
\hline 39 & Guinea-Bissau & $\star$ & & & & & \\
\hline 40 & Haiti & $\star$ & $\star$ & & & & \\
\hline 41 & Honduras & $\star$ & $\star$ & & & & \\
\hline 42 & Hong Kong & $\star$ & $\star$ & $\star$ & & & \\
\hline 43 & Iceland & $\star$ & $\star$ & $\star$ & $\star$ & & \\
\hline 44 & India & $\star$ & $\star$ & $\star$ & & & \\
\hline 45 & Indonesia & & & & & & \\
\hline 46 & Iran & & & & & & \\
\hline 47 & Iraq & & & & & & \\
\hline 48 & Ireland & $\star$ & $\star$ & $\star$ & $\star$ & $\star$ & \\
\hline 49 & Israel & $\star$ & $\star$ & $\star$ & & & \\
\hline 50 & Italy & $\star$ & $\star$ & $\star$ & $\star$ & $\star$ & $\star$ \\
\hline 51 & Jamaica & $\star$ & $\star$ & & & & \\
\hline 52 & Japan & $\star$ & $\star$ & $\star$ & $\star$ & $\star$ & $\star$ \\
\hline 53 & Jordan & $\star$ & $\star$ & $\star$ & & & \\
\hline 54 & Kenya & $\star$ & & & & & \\
\hline 55 & Korea & $\star$ & $\star$ & $\star$ & & & \\
\hline 56 & Kuwait & & & & & & \\
\hline 57 & Lesotho & $\star$ & & & & & \\
\hline 58 & Liberia & $\star$ & & & & & \\
\hline 59 & Luxembourg & $\star$ & $\star$ & $\star$ & $\star$ & $\star$ & \\
\hline 60 & Madagascar & $\star$ & & & & & \\
\hline
\end{tabular}


Table A2. Choice of Countries for Various Samples (continued).

\begin{tabular}{|c|c|c|c|c|c|c|c|}
\hline \multirow[t]{2}{*}{ Index } & \multirow[t]{2}{*}{ Country } & \multicolumn{6}{|c|}{ Number of Countries $J$ in Sample } \\
\hline & & $J=102$ & $J=66$ & $J=44$ & $J=24$ & $J=22$ & $J=7$ \\
\hline 61 & Malawi & $\star$ & & & & & \\
\hline 62 & Malaysia & $\star$ & $\star$ & $\star$ & & & \\
\hline 63 & Mali & $\star$ & & & & & \\
\hline 64 & Malta & $\star$ & $\star$ & $\star$ & & & \\
\hline 65 & Mauritania & $\star$ & & & & & \\
\hline 66 & Mauritius & $\star$ & & & & & \\
\hline 67 & Mexico & $\star$ & $\star$ & & & & \\
\hline 68 & Morocco & $\star$ & $\star$ & $\star$ & & & \\
\hline 69 & Mozambique & & & & & & \\
\hline 70 & Netherlands & $\star$ & $\star$ & $\star$ & $\star$ & $\star$ & \\
\hline 71 & New Zealand & $\star$ & $\star$ & $\star$ & $\star$ & $\star$ & \\
\hline 72 & Nicaragua & $\star$ & $\star$ & & & & \\
\hline 73 & Niger & $\star$ & & & & & \\
\hline 74 & Nigeria & & & & & & \\
\hline 75 & Norway & $\star$ & $\star$ & $\star$ & $\star$ & $\star$ & \\
\hline 76 & Oman & & & & & & \\
\hline 77 & Pakistan & $\star$ & $\star$ & $\star$ & & & \\
\hline 78 & Panama & $\star$ & $\star$ & & & & \\
\hline 79 & Papua New Guinea & $\star$ & $\star$ & $\star$ & & & \\
\hline 80 & Paraguay & $\star$ & $\star$ & & & & \\
\hline 81 & Peru & $\star$ & $\star$ & & & & \\
\hline 82 & Philippines & $\star$ & $\star$ & $\star$ & & & \\
\hline 83 & Portugal & $\star$ & $\star$ & $\star$ & $\star$ & $\star$ & \\
\hline 84 & Rwanda & $\star$ & & & & & \\
\hline 85 & Saudi Arabia & & & & & & \\
\hline 86 & Senegal & $\star$ & & & & & \\
\hline 87 & Sierra Leone & $\star$ & & & & & \\
\hline 88 & Singapore & $\star$ & $\star$ & $\star$ & & & \\
\hline 89 & Somalia & $\star$ & & & & & \\
\hline 90 & South Africa & $\star$ & & & & & \\
\hline 91 & Spain & $\star$ & $\star$ & $\star$ & $\star$ & $\star$ & \\
\hline 92 & Sri Lanka & $\star$ & $\star$ & $\star$ & & & \\
\hline 93 & Sudan & $\star$ & & & & & \\
\hline 94 & Swaziland & $\star$ & & & & & \\
\hline 95 & Sweden & $\star$ & $\star$ & $\star$ & $\star$ & $\star$ & \\
\hline 96 & Switzerland & $\star$ & $\star$ & $\star$ & $\star$ & $\star$ & \\
\hline 97 & Syria & $\star$ & $\star$ & $\star$ & & & \\
\hline 98 & Taiwan & & & & & & \\
\hline 99 & Tanzania & $\star$ & & & & & \\
\hline 100 & Thailand & $\star$ & $\star$ & $\star$ & & & \\
\hline 101 & Togo & $\star$ & & & & & \\
\hline 102 & Trinidad and Tobago & $\star$ & $\star$ & & & & \\
\hline 103 & Tunisia & $\star$ & & & & & \\
\hline 104 & Turkey & $\star$ & $\star$ & $\star$ & $\star$ & & \\
\hline 105 & Uganda & $\star$ & & & & & \\
\hline 106 & Great Britain & $\star$ & $\star$ & $\star$ & $\star$ & $\star$ & $\star$ \\
\hline 107 & United States & $\star$ & $\star$ & $\star$ & $\star$ & $\star$ & $\star$ \\
\hline 108 & Uruguay & $\star$ & $\star$ & & & & \\
\hline 109 & Venezuela & & & & & & \\
\hline 110 & Yemen & & & & & & \\
\hline 111 & Zaire & $\star$ & & & & & \\
\hline 112 & Zambia & $\star$ & & & & & \\
\hline 113 & Zimbabwe & $\star$ & & & & & \\
\hline 114 & Burma & $\star$ & $\star$ & $\star$ & & & \\
\hline 115 & Guyana & & & & & & \\
\hline 116 & Benin & $\star$ & & & & & \\
\hline 117 & Burkina Faso & & & & & & \\
\hline 118 & Nepal & & & & & & \\
\hline 119 & Suriname & $\star$ & $\star$ & & & & \\
\hline
\end{tabular}




\section{Appendix B. Derivation of $\operatorname{corr}\left(\Delta y_{t}^{*}, \Delta p_{t}^{*}\right)$ and plim $\hat{c}$}

Section 3.2 analytically evaluates the effects of temporal aggregation on estimation. This appendix derives two measures of those effects: $\operatorname{corr}\left(\Delta y_{t}^{*}, \Delta p_{t}^{*}\right)$ and plim $\hat{c}$. The derivation proceeds by obtaining moments of unaveraged data, expressing moments of averaged data in terms of moments of unaveraged data, and then solving for $\operatorname{corr}\left(\Delta y_{t}^{*}, \Delta p_{t}^{*}\right)$ and plim $\hat{c}$ in terms of moments of the averaged data. Prior to the actual derivation, it is expositionally convenient to denote the economic variables $\Delta y_{t}$ and $\Delta p_{t}$ as $w_{t}$ and $x_{t}$ respectively. In that new notation, the first-order VAR in (4) may be rewritten as:

$$
\begin{aligned}
& w_{t}=a x_{t-1}+e_{t} \\
& x_{t}=b w_{t-1}+u_{t}
\end{aligned} \quad\left[\begin{array}{l}
e \\
u
\end{array}\right]_{t} \sim N I\left(\left[\begin{array}{l}
0 \\
0
\end{array}\right],\left[\begin{array}{ll}
\sigma_{e}^{2} & 0 \\
0 & \sigma_{u}^{2}
\end{array}\right]\right)
$$

where $|a b|<1$ is assumed, for the stationarity of $w_{t}$ and $x_{t}$.

Seven moments of unaveraged data are of interest:

$$
\mathcal{E}\left(w_{t}^{2}\right), \mathcal{E}\left(x_{t}^{2}\right), \mathcal{E}\left(w_{t} x_{t}\right), \mathcal{E}\left(w_{t} w_{t-1}\right), \mathcal{E}\left(x_{t} x_{t-1}\right), \mathcal{E}\left(w_{t} x_{t-1}\right) \text {, and } \mathcal{E}\left(w_{t-1} x_{t}\right) \text {. }
$$

By substitution in (A1), it follows that:

$$
\begin{aligned}
& w_{t}=(a b) w_{t-2}+\left(e_{t}+a u_{t-1}\right) \text { and } \\
& x_{t}=(a b) x_{t-2}+\left(u_{t}+b e_{t-1}\right) .
\end{aligned}
$$

Hence, the variances and covariance of the two series are:

$$
\begin{gathered}
\mathcal{E}\left(w_{t}^{2}\right)=\frac{\sigma_{e}^{2}+a^{2} \sigma_{u}^{2}}{1-(a b)^{2}} \equiv \sigma_{w}^{2}, \\
\mathcal{E}\left(x_{t}^{2}\right)=\frac{\sigma_{u}^{2}+b^{2} \sigma_{e}^{2}}{1-(a b)^{2}} \equiv \sigma_{x}^{2}, \text { and } \\
\mathcal{E}\left(w_{t} x_{t}\right)=0
\end{gathered}
$$

noting the properties of a stationary first-order autoregression and that $\mathcal{E}\left(e_{t} u_{t}\right)=0$. Because $\mathcal{E}\left(w_{t} x_{t}\right)=0$, it immediately follows that $\operatorname{corr}\left(w_{t}, x_{t}\right) \equiv \operatorname{corr}\left(\Delta y_{t}, \Delta p_{t}\right)=0$, and that the plim of the estimator from regressing $w_{t}$ on $x_{t}$ (i.e., of $\Delta y_{t}$ on $\Delta p_{t}$ ) is also zero.

By substitution using (A1), the remaining four expectations are:

$$
\begin{gathered}
\mathcal{E}\left(w_{t} w_{t-1}\right)=a \mathcal{E}\left(w_{t-1} x_{t-1}\right)+\mathcal{E}\left(e_{t} w_{t-1}\right)=0, \\
\mathcal{E}\left(x_{t} x_{t-1}\right)=b \mathcal{E}\left(w_{t-1} x_{t-1}\right)+\mathcal{E}\left(u_{t} x_{t-1}\right)=0,
\end{gathered}
$$




$$
\begin{aligned}
& \mathcal{E}\left(w_{t} x_{t-1}\right)=a \mathcal{E}\left(x_{t-1}^{2}\right)+\mathcal{E}\left(e_{t} x_{t-1}\right)=a \sigma_{x}^{2}, \quad \text { and } \\
& \mathcal{E}\left(w_{t-1} x_{t}\right)=b \mathcal{E}\left(w_{t-1}^{2}\right)+\mathcal{E}\left(u_{t} w_{t-1}\right)=b \sigma_{w}^{2} .
\end{aligned}
$$

Deriving $\operatorname{corr}\left(\Delta y_{t}^{*}, \Delta p_{t}^{*}\right)$ and plim $\hat{c}$ requires three (averaged) data moments, all obtained by solving for the averaged data in terms of the unaveraged data and then using the expectations derived above. The two-period data averages are denoted $w_{t}^{*}$ and $x_{t}^{*}$ and are defined as $w_{t}^{*}=\left(w_{t}+w_{t-1}\right) / 2$ and $x_{t}^{*}=\left(x_{t}+x_{t-1}\right) / 2$. The three required moments for the averaged data are:

$$
\begin{gathered}
\mathcal{E}\left(w_{t}^{*} w_{t}^{*}\right)=\frac{\mathcal{E}\left(w_{t}^{2}+2 w_{t} w_{t-1}+w_{t-1}^{2}\right)}{4}=\frac{\sigma_{w}^{2}}{2}, \\
\mathcal{E}\left(x_{t}^{*} x_{t}^{*}\right)=\frac{\mathcal{E}\left(x_{t}^{2}+2 x_{t} x_{t-1}+x_{t-1}^{2}\right)}{4}=\frac{\sigma_{x}^{2}}{2}, \text { and } \\
\mathcal{E}\left(w_{t}^{*} x_{t}^{*}\right)=\frac{\mathcal{E}\left(w_{t} x_{t}+w_{t} x_{t-1}+w_{t-1} x_{t}+w_{t-1} x_{t-1}\right)}{4}=\frac{b \sigma_{w}^{2}+a \sigma_{x}^{2}}{4} .
\end{gathered}
$$

Letting $s^{2} \equiv \sigma_{w}^{2} / \sigma_{x}^{2}$ and substituting from (A11)-(A13), the correlation $\operatorname{corr}\left(w_{t}^{*}, x_{t}^{*}\right)$ is:

$$
\operatorname{corr}\left(w_{t}^{*}, x_{t}^{*}\right)=\frac{\mathcal{E}\left(w_{t}^{*} x_{t}^{*}\right)}{\sqrt{\mathcal{E}\left(w_{t}^{*} w_{t}^{*}\right) \cdot \mathcal{E}\left(x_{t}^{*} x_{t}^{*}\right)}}=\frac{a s^{-1}+b s}{2},
$$

which is equivalently $\operatorname{corr}\left(\Delta y_{t}^{*}, \Delta p_{t}^{*}\right)$. Similarly, plim $\hat{c}$ is:

$$
\operatorname{plim} \hat{c}=\frac{\mathcal{E}\left(w_{t}^{*} x_{t}^{*}\right)}{\mathcal{E}\left(x_{t}^{*} x_{t}^{*}\right)}=\frac{a+b s^{2}}{2},
$$

where the first equality follows from standard theorems on asymptotics by Slutsky and by Mann and Wald, and where the probability limit is taken as $J \rightarrow \infty$.

In calculating $\operatorname{corr}\left(w_{t}^{*}, x_{t}^{*}\right)$ or plim $\hat{c}$ numerically, as in Figure 2, it is helpful to note that $s^{2}$ can be rewritten as:

$$
s^{2} \equiv \frac{\sigma_{w}^{2}}{\sigma_{x}^{2}}=\frac{a^{2}+r^{2}}{1+b^{2} r^{2}},
$$

where $r^{2} \equiv \sigma_{e}^{2} / \sigma_{u}^{2}$. 


\section{References}

Ahmed, S., and J. H. Rogers (2000) "Inflation and the Great Ratios: Long Term Evidence from the U.S.", Journal of Monetary Economics, 45, 1, 3-35.

Barro, R. J. (1991) "Economic Growth in a Cross Section of Countries", Quarterly Journal of Economics, 106, 2, 407-443.

Barro, R. J. (1997) Determinants of Economic Growth: A Cross-country Empirical Study, MIT Press, Cambridge, Massachusetts.

de Brouwer, G., and N. R. Ericsson (1998) "Modeling Inflation in Australia", Journal of Business and Economic Statistics, 16, 4, 433-449.

Campos, J., N. R. Ericsson, and D. F. Hendry (1990) "An Analogue Model of Phaseaveraging Procedures", Journal of Econometrics, 43, 3, 275-292.

Campos, J., N. R. Ericsson, and D. F. Hendry (1996) "Cointegration Tests in the Presence of Structural Breaks", Journal of Econometrics, 70, 1, 187-220.

Church, K. B., P. R. Mitchell, and K. F. Wallis (1998) "Short-run Rigidities and Long-run Equilibrium in Large-scale Macroeconometric Models", Chapter 9 in S. Brakman, H. van Ees, and S. K. Kuipers (eds.) Market Behaviour and Macroeconomic Modelling, Macmillan, London, 221-241.

Clark, T. E. (1997) "Cross-country Evidence on Long-run Growth and Inflation", Economic Inquiry, 35, 1, 70-81.

Cozier, B., and J. Selody (1992) "Inflation and Macroeconomic Performance: Some Cross-country Evidence", Working Paper No. 92-6 (Revised), Bank of Canada, Ottawa, Canada, November.

Doornik, J. A., and D. F. Hendry (1996) PcGive Professional 9.0 for Windows, International Thomson Business Press, London.

Englander, A. S., and A. Gurney (1994) "Medium-term Determinants of OECD Productivity", OECD Economic Studies, 22, Spring, 49-109.

Evans, P. (1997) "How Fast Do Economies Converge?", Review of Economics and Statistics, 79, 2, 219-225.

Fischer, S. (1991) "Growth, Macroeconomics, and Development", NBER Macroeconomics Annual, 1991, 329-379 (with comments).

Franz, W., and R. J. Gordon (1993) "German and American Wage and Price Dynamics: Differences and Common Themes", European Economic Review, 37, 4, 719-754 (with discussion).

Granger, C. W. J. (1969) "Investigating Causal Relations by Econometric Models and Cross-spectral Methods", Econometrica, 37, 3, 424-438. 
Grier, K. B., and G. Tullock (1989) "An Empirical Analysis of Cross-national Economic Growth, 1951-80", Journal of Monetary Economics, 24, 2, 259-276.

Hendry, D. F., and G. E. Mizon (1998) "Exogeneity, Causality, and Co-breaking in Economic Policy Analysis of a Small Econometric Model of Money in the UK", Empirical Economics, 23, 3, 267-294.

Hendry, D. F., and G. E. Mizon (1999) "The Pervasiveness of Granger Causality in Econometrics", Chapter 5 in R. F. Engle and H. White (eds.) Cointegration, Causality, and Forecasting: A Festschrift in Honour of Clive W. J. Granger, Oxford University Press, Oxford, 102-134.

Hendry, D. F., A. R. Pagan, and J. D. Sargan (1984) "Dynamic Specification", Chapter 18 in Z. Griliches and M. D. Intriligator (eds.) Handbook of Econometrics, Volume 2, North-Holland, Amsterdam, 1023-1100.

Hutchison, M. M., and C. E. Walsh (1998) "The Output-Inflation Tradeoff and Central Bank Reform: Evidence from New Zealand", Economic Journal, 108, 448, $703-725$.

Johansen, S. (1991) "Estimation and Hypothesis Testing of Cointegration Vectors in Gaussian Vector Autoregressive Models", Econometrica, 59, 6, 1551-1580.

Knight, M., N. Loayza, and D. Villanueva (1993) "Testing the Neoclassical Theory of Economic Growth: A Panel Data Approach", IMF Staff Papers, 40, 3, 512-541.

Kormendi, R. C., and P. G. Meguire (1985) "Macroeconomic Determinants of Growth: Cross-country Evidence", Journal of Monetary Economics, 16, 2, 141-163.

Leamer, E. E. (1985) "Sensitivity Analyses Would Help", American Economic Review, $75,3,308-313$.

Lee, K., M. H. Pesaran, and R. Smith (1997) "Growth and Convergence in a Multicountry Empirical Stochastic Solow Model", Journal of Applied Econometrics, 12, 4, 357-392.

Levine, R. (1998) "The Legal Environment, Banks, and Long-run Economic Growth", Journal of Money, Credit, and Banking, 30, 3, Part 2, 596-613.

Levine, R., and D. Renelt (1991) "Cross-country Studies of Growth and Policy: Methodological, Conceptual, and Statistical Problems", PRE Working Paper Series, WPS 608, Country Economics Department, World Bank, Washington, D.C., March.

Levine, R., and D. Renelt (1992) "A Sensitivity Analysis of Cross-Country Growth Regressions", American Economic Review, 82, 4, 942-963.

Levine, R., and S. Zervos (1998) "Stock Markets, Banks, and Economic Growth", American Economic Review, 88, 3, 537-558. 
Mankiw, N. G., D. Romer, and D. N. Weil (1992) "A Contribution to the Empirics of Economic Growth", Quarterly Journal of Economics, 107, 2, 407-437.

Osterwald-Lenum, M. (1992) “A Note with Quantiles of the Asymptotic Distribution of the Maximum Likelihood Cointegration Rank Test Statistics", Oxford Bulletin of Economics and Statistics, 54, 3, 461-472.

Romer, P. M. (1986) "Increasing Returns and Long-run Growth", Journal of Political Economy, 94, 5, 1002-1037.

Sala-i-Martin, X. X. (1997) "I Just Ran Two Million Regressions", American Economic Review, 87, 2, 178-183.

Sargan, J. D. (1964) "Wages and Prices in the United Kingdom: A Study in Econometric Methodology", in P. E. Hart, G. Mills, and J. K. Whitaker (eds.) Econometric Analysis for National Economic Planning, Volume 16 of Colston Papers, Butterworths, London, 25-54 (with discussion).

Sargan, J. D. (1980a) "The Consumer Price Equation in the Post War British Economy: An Exercise in Equation Specification Testing", Review of Economic Studies, $47,1,113-135$.

Sargan, J. D. (1980b) "A Model of Wage-price Inflation", Review of Economic Studies, $47,1,97-112$.

Summers, R., and A. Heston (1991) "The Penn World Table (Mark 5): An Expanded Set of International Comparisons, 1950-1988", Quarterly Journal of Economics, $106,2,327-368$.

Temple, J. (1999) "The New Growth Evidence", Journal of Economic Literature, 37, $1,112-156$. 